\title{
Indefra og udefra - serendipitet som kunstfagdidaktisk princip i Teater Bag Murene
}

\author{
Af Kristian Nødtvedt Knudsen ${ }^{\star}$ og Marianne Nødtvedt Knudsen \\ Universitetet $i$ Agder
}

\begin{abstract}
Sammendrag
Udgangspunktet for denne studie skal findes i et kunstnerisk projekt med det norske scenekunstkompagni Teater Bak Murene. I foråret 2019 arbejdede kompagniet med at udvikle forestillingen Innefra og Ut, som blev vist og udviklet sammen med indsatte i Trondheim Fængsel i forbindelse med dansefestivallen Multiplié. I vores undersøgelse af arbejdet med Innefra og Ut fokuserer vi på de kunstfagdidaktiske potentialer, som opstår i krydsfeltet mellem det kunstneriske udviklingsarbejde, deltagerne og publikums møde med forestillingen. I analysen gennemfører vi en fænomen-grafering (Juelskjær, 2019) af to hændelser fra forestillingen. Gennem fænomen-graferingen og begreberne serendipitet, som vi henter fra teaterteori, samt intra-aktion og agens (Barad, 2007; Juelskjær, 2019) åbner vi op for at bringe et væld af forbindelser, både af menneskelige og ikke-menneskelige karakterer, med ind $i$ analysen af forestillingen. Hensigten med artiklen er at undersøge, hvordan serendipitet som kunstfagdidaktisk princip kan bringes med ind i udviklingen af- og mødet med en teaterforestilling.
\end{abstract}

Nøgleord: Teater i fengsel; serendipitet; performativ forskning; intra-aktion; fanomengrafering

Received: June, 2020; Accepted: November, 2020; Published: December, 2020

\begin{abstract}
Inside and Out - Serendipity as an arts' educational principle in Theatre Behind Walls

The starting point for this study is an artistic project with the Norwegian performing arts company Theatre Behind Walls (Teater Bak Murene). In the spring of 2019, the company developed the performance called Inside and Out, which was performed and developed together with inmates in Trondheim Prison in connection with the dance festival Multiplié. In our study we focus on the arts' educational potential that arise at the crossing between the artistic process, the participants and the audience experience with the performance. In the analysis, we carry out a genealogical mapping analysis (Juelskjær, 2019) of two situations from the performance. Through the analysis and the concepts of serendipity, which we derive from theater theory, as well as intra-action and agency (Barad, 2007; Juelskjær, 2019), we bring a wealth of connections, both of human and
\end{abstract}

^Korrespondanse: Kristian Nødtvedt Knudsen, e-post: kristian.n.knudsen@uia.no

(C) 2020 K. N. Knudsen \& M. N. Knudsen. This is an Open Access article distributed under the terms of the Creative Commons Attribution 4.0 International License (https://creativecommons.org/licenses/by-nc/4.0/), allowing third parties to copy and redistribute the material in any medium or format and to remix, transform, and build upon the material for any purpose, even commercially, provided the original work is properly cited and states its license.

Citation: K. N. Knudsen $\Xi$ M. N. Knudsen. «Indefra og udefra-serendipitet som kunstfagdidaktisk princip $i$ teater bag murene». fournal for Research in Arts and Sports Education, Special issue: Fysisk aktivitet, kropp og bevegelse i barnehagen, 


\section{K. N. Knudsen $\mathcal{G}$ M. N. Knudsen}

non-human nature, into the analysis of the performance. The purpose of the article is to investigate how serendipity as an arts' educational principle can be brought into the development of and the encounter with a theatrical performance.

Keywords: Theatre in Prison; serendipity; performative research; intra-action; genealogical mapping

Udgangspunktet for denne studie skal findes i et kunstnerisk projekt med det norske scenekunstkompagni Teater Bak Murene (TBM). I foråret 2019 arbejdede kompagniet med at udvikle forestillingen Innefra og Ut, som blev vist og udviklet sammen med indsatte i Trondheim Fængsel i forbindelse med dansefestivallen Multiplié. Artiklens titel er hentet herfra, men eftersom vi begge var involverede på forskellige måder i arbejdet med og gennemførelsen af forestillingen, bringer vi også indefraog udefra- perspektiverne med ind i måden, vi skriver artiklen på. Artiklens forfatter 2 (Marianne) deltog som scenekunstner og havde ansvar for regi i forbindelse med udviklingen og gennemførelsen af forestillingen, og hun repræsenterer artiklens indefra- perspektiv. Artiklens forfatter 1 (Kristian) deltog som publikummer, og han repræsenterer et udefra- perspektiv. Men der er også et tredje og mere sammenflettet perspektiv til stede, og det er det faktum, at vi er gift. Det betyder blandt andet, at mens det kunstneriske arbejde pågik, satte det sit præg på vores hverdag og samliv. Hændelser fra processerne blev diskuteret, og ideer blev videreudviklet mellem hjemmets fire vægge. Ovenstående præmisser medfører, at vi som forskere er positioneret tæt på den kunstneriske praksis vi forsker i, og vi skriver os dermed ind i et performativt forskningsparadigme (Haseman, 2006; Østern \& Knudsen, 2019). Den performative forsker bringer sine værdier og forforståelse med ind i den kunstneriske praksis og bliver en del af forskningsprojektet (Gergen \& Gergen, 2018; Knudsen, 2017; Østern \& Letnes, 2017). Ligeledes medfører vores tilknytning til den kunstneriske praksis, vi forsker $i$, at vi arbejder ud fra en videnskabsfilosofisk grundpræmis om, at vi som forskere ikke er situerede udenfor eller indenfor forskningspraksissen, men, som vi vender tilbage til senere i artiklen, både er forbundet og filtret sammen med den (Barad, 2007; Juelskjær, 2019).

I vores undersøgelse af arbejdet med Innefra og Ut fokuserer vi på de kunstfagdidaktiske potentialer, som opstår i krydsfeltet mellem det kunstneriske udviklingsarbejde, deltagerne og mødet med forestillingen. Vi positionerer os således i en kunstfagdidaktisk forskningskontekst, da vi har fokus rettet mod de arenaer, som indeholder lærings- og uddannelsesprocesser i en kunstfaglig kontekst. I analysen gennemfører vi en fænomen-grafering (Juelskjær, 2019) af to hændelser fra forestillingen. Gennem fænomen-graferingen og begreberne serendipitet, intra-aktion og agens åbner vi op for at bringe et væld af forbindelser, både af menneskelige og ikke-menneskelige karakterer, med ind i analysen af forestillingen. Vi vender tilbage til begreberne senere $i$ artiklen. Hensigten med artiklen er at undersøge hvordan serendipitet som kunstfagdidaktisk princip kan bringes med ind i udviklingen og mødet med en teaterforestilling. 
Artiklen struktureres på følgende måde: vi begynder med en redegørelse for og etablering af fængslet som kunstinstitution og en kort introduktion af kompagniet TBM. Efterfølgende præsenteres begrebet serendipitet, som vi henter fra teaterteori (Chemi \& Christoffersen, 2018), Malou Juelskjærs begreb fænomem-grafering (Juelskjær, 2019) og dele af Barads agentiale realisme (Barad, 2007) med særligt fokus på intra-aktion og agens. Afslutningsvis drøfter vi, hvordan serendipitet som performativt og kunstfagdidaktisk princip kan åbne op for forskellige måder at tolke og undersøge kunstneriske processer på, når scenekunst bevæger sig ind bag murene.

\section{Teater i fængsel - fængslet som kunstinstitution}

Når vi i denne studie forsøger at etablere fængslet som en kunstinstitution, fordres nogle mellemregninger. Et fængsel er i udgangspunktet en lukket institution og som sådan også et lukket samfund, hvor afsoningen af fængselsstraf står centralt: "En fengselsstraff skal være berøvelse eller innskrenkning av frihet, ikke tap av andre grunnleggende menneskerettigheter. Kriminalomsorgen utøver stor makt over enkeltmennesker[.]" (Kriminalomsorgen, 2019). Dette medfører at den, der bliver indsat i institutionen, bliver frataget sin frihed og skal følge de love og regler, som gælder for institutionen. Fængslet er dermed både en institution, som skal udøve magt over den indsatte med den ene hånd og med den anden lægge til rette for at tilbageføre den indsatte til samfundet.

I et teaterfagligt perspektiv opereres der med forskellige indgange til og intentioner med det kunstneriske arbejde i fængslerne. Flere teaterprojekter i fængsler knytter an til det, man kan kalde et rehabiliteringsfokus, hvor de indsatte bliver rehabiliterede når de deltager i de kunstneriske processer (Balfour, 2000; Bottoms, 2010; Keehan, 2015; Tett et.al., 2012; Thompson, 1998). Andre teaterprojekter er mere rettet mod teaterproduktion og tager blandt andet udgangspunkt i et stykke dramatik, en tekst udviklet af deltagerne eller iscenesættelser af de indsattes egne livshistorier (Goddard, 2013; Prendergast, 2013; Sutherland, 2013; Woodland, 2016). I det følgende afsnit introduceres teaterkompagniet TBM og forestillingen Innefra og Ut, hvorefter vi redegør for kompagniets kunstneriske arbejde i fængslet.

\section{Teater bag murene - i krydsfeltet mellem kunst og uddannelse}

TBM har arbejdet med scenekunst i norske fængsler siden 2007. Som scenekunstkompagni arbejder TBM i krydsfeltet mellem performanceteater, dans og autobiografisk materiale/dokumentarisme. I forbindelse med udviklingen af Innefra og Ut deltog seks indsatte fra Trondheim fængsel og seks personer som kom ind udefra. Deltagerne udefra var to masterstudenter i teatervidenskab, to scenekunstnere med ansvar for musik, en scenekunstner med ansvar for koreografi og en scenekunstner med ansvar for regi. Projektet varede i 12 uger med to gange tre timers øvelser i hver uge. I løbet af de sidste to ugers arbejde blev antallet af indsatte reduceret til seks på grund af løsladelse, overførsel til andre fængsler, eller fordi de ikke ønskede at ville stå foran et publikum. Sammen dannede de 12 deltagere et midlertidigt kollektiv, som 


\section{K. N. Knudsen $\mathcal{G}$ M. N. Knudsen}

opererede indenfor fængslets restriktioner i forhold til sikkerhed, tid og økonomiske ressourcer. Størstedelen af det kunstneriske arbejde såsom valg af tematik, udvikling af tekster, koreografi og indhold blev udviklet i fællesskab. Andre elementer af mere praktisk og økonomisk karakter blevet ordnet af artiklens forfatter 2 Marianne (scenekunstner og instruktør), Hanne Aalberg (scenekunstner og koreograf) og ledelsen i Trondheim fængsel. Produktionsarbejdet foregik i fængslets kølige gymnastiksal, som var et kvadratisk rum med hvide murstensvægge og et blødt gulv i et gummiagtigt materiale. Akustikken var vanskelig at arbejde med og vinduerne plomberede, så der ikke kom frisk luft ind i lokalet. Der var ikke noget udstyr tilgængeligt, og alt udstyr skulle godkendes og kontrolleres, før det kunne tages med ind bag murene. Selve forestillingen varede cirka 45 minutter og scenografien lignede et gartneri eller et væksthus med planter, drivhuse og en grøn græsplæne. Aktørerne var iklædt træningsdragter, og de havde forskellige roller og funktioner undervejs. Der var ikke nogen tydelig form for fiktionskontrakt eller fiktive karakterer, så aktørernes roller indgik i et kollektivt udtryk. Forestillingens dramaturgiske opbygning bestod af fragmenter af autobiografisk materiale, der relaterede sig til temaer om uro og begrænsninger i livet, både bag og udenfor murene. Enkelte fragmenter indeholdt også selvskrevne tekster, mens andre bestod af danse- og bevægelsessekvenser.

I denne studie befinder teateret bag murene sig i et krydsfelt mellem det kunstneriske og det kunstpædagogiske. På den ene side er der tale om et uddannelsestilbud i fængslet som uddannelsesinstitution, som medfører et kunstpædagogisk blik på udviklingen og gennemførelsen af den teaterfaglige undervisning. På den anden side bliver det kunstneriske team, Marianne og Hanne, ansat til at gennemføre arbejdet med at igangsætte og gennemføre en proces som resulterer i en forestilling på Multiplié dansefestival. Dette medfører, at fængslet transformeres til en kunstinstitution.

\section{Serendipitet - kunstneriske benspænd eller læring uden retning}

Ifølge Tatiana Chemi og Erik Exe Christoffersen (2018) er serendipitet ikke en bestemt procedure, men både en kollaborativ proces og en type selvlæring, hvor improvisation og evnen til at skabe forbindelser mellem ellers adskilte elementer vægtlægges. Processen adskiller sig således på nogle områder fra andre kollektive arbejdsformer i en teaterkontekst, som for eksempel devising, da der blandt andet ikke er samme type faseinddeling, som kendetegner en devising styret proces (Haagensen, 2014). Serendipitetsbegrebet stammer oprindeligt fra den engelske forfatter Horace Walpole i 1754, men anvendes i nyere tid som en katalysator eller et kunstnerisk princip i arbejde med teater (Barba, 2004). Eugenio Barba påpeger, at serendipitet kan forstås som en uventet gevinst: "Vi bygger i blinde. Vi ved, hvordan vi skal søge, men vi ved endnu ikke hvad" (Barba, 2004, s. 57). Hos Barba kan der spores en eksplorerende tilgang til den skabende proces, man er en del af, samt et element af risikotagning og en vilje til at fejle. Det er derfor nødvendigt, at deltagerne i processen kan håndtere det kaos eller den usikkerhed, som følger i kølvandet, og lærer sig at udnytte "fejlene" og gøre dem til udgangspunkt for 
uventede muligheder. Viljen til at risikere at fejle og en eksplorerende tilgang er også centrale omdrejningspunkter, når begrebet adapteres til en kunstfagdidaktisk kontekst. Chemi og Christoffersen påpeger blandt andet, at det fordrer en opmærksom, åben og sensorisk årvågenhed i forhold til de umiddelbare fysiske og sociale omgivelser, selv om de ved første blik kan virke ubetydelige (Chemi \& Christoffersen, 2018, s. 39-40). Læring rettes således ikke mod noget konkret og forudbestemt, men er transformativ, dynamisk, relationel, selvrefleksiv og sensorisk. Chemi og Christoffersen beskriver serendipitet som en rejse i fremmede lande, hvor adfærd, vaner og normer gør det vanskeligt at orientere sig. Pludselig bliver man klar over, at man befinder sig et helt andet sted, end man regnede med. En del af arbejdet med serendipitet indebærer et uventet fund, som får en konsekvens for den videre rejse: "Det er tale om et brud med den indlærte kropslige og mentale viden og vanetænkning, som spærrer for nye opdagelser og indsigter" (Chemi \& Christoffersen, 2018, s. 261). Denne type brud kan opleves som rystende eller ubehagelige, da man bryder med rutineprægede handlingsmønstrer. En forudsætning for serendipitet er således tillid til den kontekst eller gruppe, man er en del af, og et miljø, hvor den enkelte høres og anerkendes i sin forskellighed.

\section{Den kunstneriske praksis bag murene i lys af agential realisme}

I denne studie lader vi os inspirere af posthumanistisk teori (Barad, 2007; Juelskjær, 2019). I en videnskabsfilosofisk kontekst indeholder posthumanisme en afstandtagen fra fastholdelsen af distinktioner mellem subjekt/objekt, teori/praksis og diskurs/ materialitet. Posthumanisme kendetegnes i stedet af, at diskurser, materialitet og fænomener er sammenfiltrede og i intra-aktion med hinanden (Barad, 2003; Braidotti, 2013). Barad beskriver sin version af post-humanistisk tænkning, agential realisme, som værende ethico-onto-epistemologisk, da den hævder, at væeren er uløseligt sammenfiltret med kundskab om verden. Forskere er også del af verden, samtidig som de forsker, og når de forsøger at sige noget om verden, skaber de samtidig verden. Verden er altså materiel-diskursiv, sammenfiltret. Deri ligger der også et etisk aspekt, da kundskab om verden og alle valg, som er forbundet med dette, samtidig skaber nye forståelser af verden. Det etiske aspekt gør sig også gældende med tanke på fængselsteater, som er fænomenet, vi studerer.

Intra-aktion er et centralt begreb i Barads agentiale realisme (Barad, 2007, s. 139-141). I modsætning til interaktion, som fastholder distinktionen mellem to separate punkter, refererer intra-aktion til relationelle aspekter, hvor menneskelige og ikke-menneskelige materialiteter og diskurser, som omgiver og producerer os, er sammenfiltrede og gensidigt afhængige af hinanden. Som forsker kan man studere materielt-diskursive fænomener, samtidig med at man er en del af fænomenerne. Det agentiale viser hen til måden, materialiteter intra-agerer og ko-konstitueres af hinanden og i situationen. At noget bliver agentisk, handler om at bidrage til at få noget til at ske, ikke som autonome subjekter, men som performative agenter i sammenfiltrede relationer. Ifølge Barad er agentialitet det mulighedsrum, som åbner sig, idet 


\section{K. N. Knudsen $\mathcal{G}$ M. N. Knudsen}

agentiale snit [agential cut] i intra-aktionen afgør, hvad noget bliver til (Dolphijn \& van der Tuin, 2012, s. 54). Juelskjær (2019) introducerer analyseredskabet fænomengrafering som en oversættelse af Barads "genealogical mapping", som Barad henter fra Foucault (Barad, 2007). Ifølge Juelskjær handler det om; "[...] at gå fra ting til fænomen eller så at sige at fænomengøre sin genstand i agential realistisk forstand, og hvor grafi og grafering markerer den "mapping"-proces, som finder sted i og med undersøgelsesprocessen" (Juelskjær, 2019, s. 101). Relationelle og etiske aspekter vægtlægges og forskeren er i kraft af dette også viklet ind i selve tilblivelsen af undersøgelsesprocessen ${ }^{1}$. Juelskjær foreslår, at man gennem en kaskade af spørgsmål åbner op for at gribe det materielt-diskursive fænomen an på en eksplorativ og undrende måde. En del af fænomen-graferingen indebærer at tage fat i diverse hændelser, som er med til at oparbejde og producere viden om de forskellige forbindelsers karakter og effekter. Efterfølgende begynder man at bøje og brydes med de forskellige forbindelser ved at stille skarpt på forskelle, fravær og tavshed. Det vil sige, fænomenet leeses gennem noget andet. Dette kaller Barad diffraktiv leesning. At læse diffraktivt handler om en bevægelse, som Barad kalder cutting-together-apart (Barad, 2014). Cuttingtogether betyder, at der åbnes op for at fryse performative agenter, som har betydning for at skabe fænomenet, mens cutting-apart indebærer at læse de performative agenter diffraktivt med teoretiske begreber og dermed rekonfigurere og skabe ny mening. I denne studie er det blandt andet serendipitetsbegrebet, som vi bringer med ind i den diffraktive læsning af både mødet med og udviklingen af forestillingen Innefra og Ut.

\section{Fænomen-grafering af Innefra og Ut}

I denne studie gør vi en fænomen-grafering af forestillingen Innefra og Ut. Vi fastfryser to øjeblikke (cutting-together i agentiale snit) fra forestillingen for derigennem at undersøge samspillet mellem forskellige agenter og muligheder, som træder frem (cutting-apart). Derigennem flyttes fokus væk fra opfattelsen af forestillingen som en isoleret hændelse bestående af scenografi, et dramatisk indhold og nogle aktører på scenen og transformeres fra at være et objekt eller en enhed til at blive et fænomen. Vi tager med udgangspunkt $i$ agens fat på specifikke forbundetheder $i$ form af tilblivende diskurser og materialitet og produktive processer og praksisser, som alle er med til at gøre forestillingen til det, som den bliver. Det indebærer at begynde at lede efter brydninger og forbindelser, som betyder en forskel i relation til måden mening og læring skabes på, eller i en skabende praksis som ophæver binariteter og skaber nye forbindelser (Juelskjær, 2019, s. 57). Barads agentiale realisme og intra-aktion samt Juelskjærs fænomen-grafering bliver således både en teoretisk og analytisk platform, hvorfra vi undersøger serendipitet som kunstfagdidaktisk princip i udviklingen og mødet med Innefra og Ut.

\footnotetext{
${ }^{1}$ For en mere grundig gennemgang af Juelskjærs fænomen-grafering og teorier bag henvises læseren til kapitel 4-7 i Juelskjær, 2019.
} 


\section{Agential snit - hændelse nummer et}

Vi arbejder $i$ en gymnastiksal. På gulvet ligger der fem stykker papir. Hvert papir indeholder et ord. Ordene er håb, hevn, skyld, frihed og begrensning. Både ordene og øvelsen, vi skal $i$ gang med, er hentet fra performancegenren. Ved siden af hvert papir ligger der en bunke post-it notes og blyanter. Deltagerne fordeler sig $i$ mindre grupper og valger et ord, hvorefter de begynder at brainstorme med udgangspunkt $i$ ordet. Efter lidt tid bevager de sig videre til et nyt papir med et nyt ord og fortscetter med en ny runde brainstorming. Til sidst er de tilbage ved det første stykke papir og begynder at skabe poetiske tekster eller found poems. ${ }^{2}$ Med udgangspunkt $i$ alle ordene, som står på deres papir, skaber deltagerne et found poem. Et af digtene blev fremfort som en monolog af en af aktørerne i forestillingen:

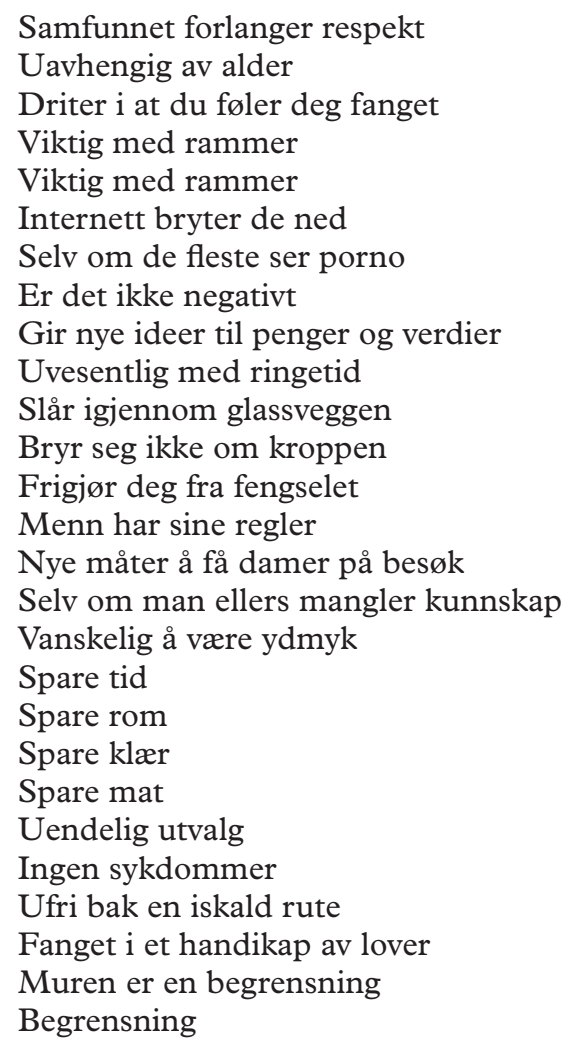

\section{Benspænd og affektive strømninger}

De performative agenter, som vi lægger mærke til i det første agentiale snit, er kunstneriske benspend og materialiteten $i$ fengsel. Begge performative agenter intra-agerer med deltagerne i skabende processer, hvorigennem der skabes ideer og poetiske

\footnotetext{
${ }^{2}$ Found poem eller found poetry er en måde at skabe digt eller poetiske tekster på, hvor man bruger ord fra magasiner, lister, e-mail eller lignende (Faulkner, 2018, s. 215).
} 


\section{K. N. Knudsen $\mathcal{G}$ M. N. Knudsen}

formuleringer. Med udgangspunkt i de fem ord (håb, hæevn, frihed, begrcensning og skyld) valgt af Marianne igangsættes arbejdet med at udvikle tekstmateriale. Materialet videreudvikles gennem en kollaborativ og improvisatorisk proces, hvor associationer over de forskellige ord sættes sammen, brydes op- og eksperimenteres med. På dette tidspunkt fokuserer jeg (Marianne) på at skabe tekstmateriale, og processen er åben og uden begrænsninger i forhold til, hvilke indspil der kan udforskes og arbejdes videre med. Senere i processen samles alt materiale, hvorefter vi i fællesskab udvælger hvilke dele, som skal med videre i arbejdet mod den endelige forestilling. De kunstneriske benspænd kommer blandt andet til syne i processens improvisatoriske dimension, da der forudsættes en åbenhed fra deltagerne overfor de indspil, der dukker op, og en vilje til at gribe fat i noget konkret og spinde videre på det. Hvilket også fordrer en vilje til at turde at risikere, at der ikke spindes videre på det, der opstår i processen. Denne eksplorerende tilgang ræsonnerer med serendipitetsbegrebet, og vi vil fremhæve den som et kunstfagdidaktisk princip, da det er et centralt omdrejningspunkt for den skabende proces. Startpunkterne er dynamiske og transformative. De skaber undring, modstand og inspiration hos deltagerne, som igen fører til skabelsen af nye ord og sætninger på de forskellige stykker papir. I løbet af processen begynder digtet gradvist at tage form. Deltagernes udforskning og måde at sætte ordene sammen på ender til sidst i noget uventet, som er skabt gennem deltagernes brydninger mellem ord, tekst, mening og i form af verbal og non-verbal kommunikation.

Fængslets materialitet præger den kunstneriske proces, da både deltagerne, ansatte, fængslet som institution og det rumlige aspekt $\mathrm{i}$ form af mure, lukkede rum og låste døre bidrager til, at noget sker. I digtet kommer dette noget for eksempel til udtryk i omtalen af murene som begrænser, men som paradoksalt nok alligevel transformeres til en poetisk tekst, som fremføres i forestillingen. En anden agens, som også spiller ind, er mødet mellem scenekunstnerne udefra og de indsatte, som bliver en sammensat gruppe deltagere, som skaber en egen form for agens i processen. Scenekunstnerne tilfører forestillingen og udviklingen af denne en form og ramme. Ikke som en individuel kunstnersignatur, men i form af en stringens og kompetence, som blandt andet bliver synlig gennem forestillingens dramaturgiske opbygning, sceniske udtryk og forestillingen som helhed. De indsatte tilfører autenticitet og materiale gennem deres personlige historier, kroppe og erfaringer. Materialiteten i fængslet bidrager også med et element af autenticitet i intra-aktionen mellem digtet, aktørerne på scenen, aktøren som fremfører teksten, publikum og fængslet som institution. De rå mure, lugten af gammel tobak, kaffe og indelukkethed. Den knasende lyd fra vagternes Intercom, som interferer er med både gruppeøvelser i øveperioden og med publikum under gennemførelsen af selve forestillingen. Gymnastiksalens larmende akustik og lyden af nøglerne i kæder, som rasler ved den mindste bevægelse. Autenticiteten kommer til udtryk på flere forskellige måder afhængigt af diskursen og situationen, fænomenet opstår i. For eksempel mærker jeg (Kristian) som publikummer, hvordan indslusningen i fængslet og kontrolleringen af vagterne, som fremdeles sidder i min krop, forstærkes, når jeg ser digtet fremført af den ensomme person, som står på scenen. De forskellige former 
for affektive strømninger, som løber gennem min krop, bringes med ind i mødet med forestillingen og når jeg intra-agerer med den som publikummer. Disse øjeblikke kan karakteriseres som en form for serendipitet $\mathrm{i}$ form af at være brydninger eller benspænd, som medvirker til, at jeg i mit møde med forestillingen mærker og sanser noget nyt og noget uventet (jf. Chemi \& Christoffersen, 2018). Mødet er også et eksempel på, hvordan jeg som publikummer og forsker bliver formet gennem hver intra-aktion og hver udforskning af potentielle forbindelser. I intra-aktion med fængslets materialitet og som publikummer/forsker/ægtefælle bliver jeg anderledes mig selv.

\section{Agentialt snit - hændelse nummer to}

Aktørene kommer ud af drivhuset med en spand på hovedet. De positionerer sig $i$ en formation. Langsomt griber de fat $i$ spandene og løfter dem opad. De afslører først, hvem der er inde $i$ spanden, tredje gang de løfter. Spanden bliver vendt om som en kikkert eller et øje, der ser ud over publikum. Spanden placeres tilbage på hovedet igen. Famlende finder spandene deres partner, og de omfavner hinanden. Aktørerne er klcedt i trceningsdragter med sorte bukser, og overdele $i$ rød, grøn eller blå. Plastikspandene er hvide. Foran på scenen er der grønne levende planter, gulvet er dekket med gresplener og strimler af planter henger ned over bagvaggen. I venstre side af scenen er et drivhus. Over musikanlagget spilles "You gotta keep moving" af Airwaves.

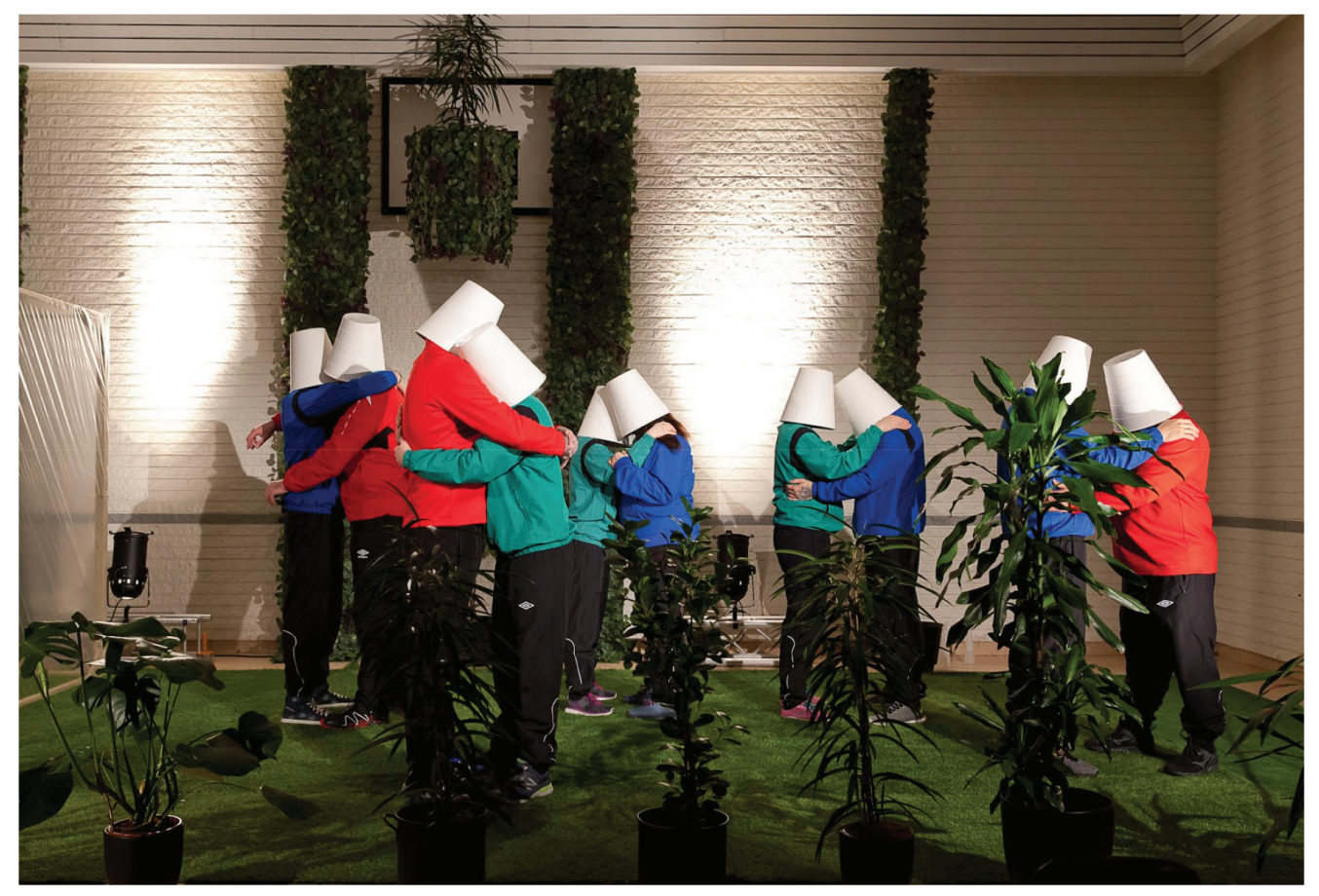

Foto: Rune Hansen, 2019. 


\section{K. N. Knudsen $\mathcal{E}$ M. N. Knudsen}

\section{Materialitet og krop}

Igennem dette agentiale snit skaber vi følgende to performative agenter: rummets materialitet og krop. Rummets materialitet indeholder både kostumer, scenografiske elementer, lys og rekvisitter. Farverne på kostumerne og spandene på aktørenes hoveder, bidrager til, at aktørerne fremstår som "noget andet" end menneskelige karakterer. De bliver identitetsløse figurer eller en form for robotter. Der er både noget menneskeligt og ikke-menneskeligt til stede i disse figurer og deres udtryk. Denne form for leg med det kendte og det ukendte genspejles også i rummets materialitet. Rummet vi befinder os i, er fængslets gymnastiksal, men i intra-aktionenen opstår nye forbindelser og forbundetheder. For de indsatte som deltager i projektet, så forandres deres erfaringer med omgivelserne, da de aktiviteter, som plejer at foregå i gymnastiksalen, er forandrede. De nye omgivelser stimulerer til undring eller sensorisk årvågenhed overfor de nye fysiske og sociale omgivelser (jf. Chemi \& Christoffersen, 2018). Sammenfletningen af det kendte og ukendte i rummets materialitet bliver en performativ agens, som intraagerer med både publikum, aktørerne og fængslet som institution.

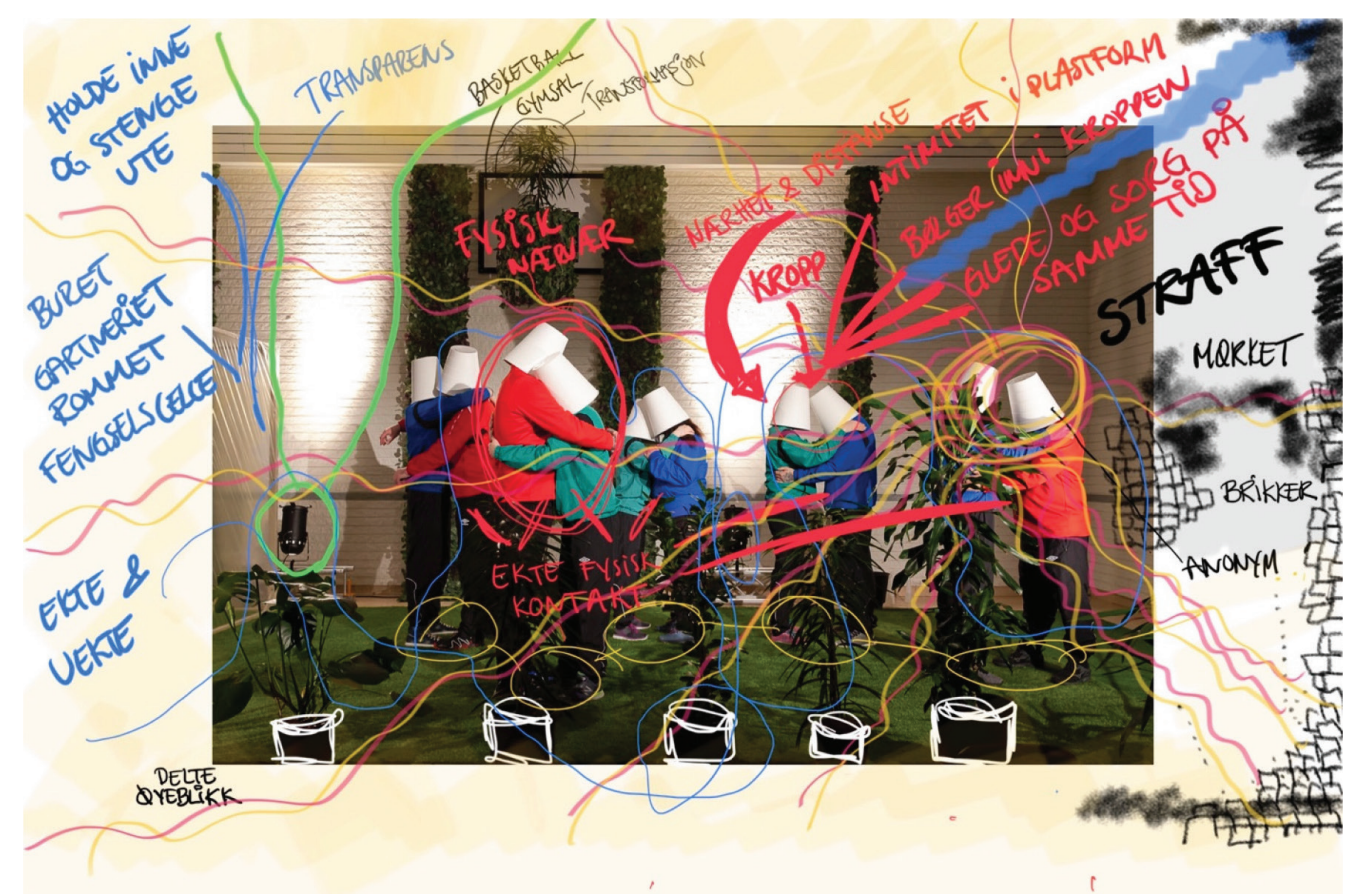

Billede 1. I billedet har vi gennem en performativ tilnærmelse til forskningsmaterialet, som vi selv er en del af, forsøgt at illustrere, hvordan vi oppfatter intra-aktiv sammenfiltring, og hvordan forskellige former for performativ agens opstår. (Design: Marianne Nødtvedt Knudsen)

Den anden performative agent, som vi skaber i dette snit, er krop. I mødet med kroppene på scenen (2019) bider jeg (Kristian) mærke i deres forskellighed. De 
har forskellige højder og forskellige størrelser. De er anonyme og figurative og fremstår på en og samme tid som et kollektiv og som noget autonomt. Kroppene holder om hinanden på forskellige måder. Nogle forbliver langt fra hinanden, andre er i en intim omfavnelse. Nogle af spandene rører ved hinanden, mens andre er på afstand af hinanden. I dette møde opstår en spænding i de forskellige måder kroppene er positioneret på. Den indsattes krop, som med sine muskler og tatoveringer udstråler hårdhed og maskulinitet, bliver pludselig sårbar. Denne spænding skaber affektive strømninger i mig (Kristian), og min opfattelse af den indsattes krop forandres.

I udviklingen af sekvensen med de hvide spande, improviserer deltagerne med tempo og dynamik. De udforsker forskellige statuepositurer og eksperimenterer med overgangene mellem de forskellige positurer. ${ }^{3}$ Denne del af processen er åben, eksperimenterende og uden begrænsninger. I fællesskab tester deltagerne forskellige indfald med spandende og materialet er i konstant udvikling. På et tidspunkt er der en af deltagerne, som tager spanden på hovedet. Vi, aktørene i forestillingen, griner. Det ser sjovt ud. Flere af deltagerne tager spandene på hovedet. Jeg (Marianne) mærker, hvordan kropslige strømninger i form af kuldegysninger og tårer i øjnene er med til at skærpe mit fokus på det, som sker i denne hændelse. Jeg oplever det, som et stærkt øjeblik, da jeg på den ene side er en del af kollektivet indenfor murene og på den anden side også er en del af samfundet udenfor murene. De konstante brydninger mellem det synlige og usynlige, det indelukkede og det frie, kan også findes i brydningerne mellem fængslets opgave som straffeanstalt og som ansvarlig for at føre kriminelle tilbage til samfundet. Sekvensen med spandene opstår tilfældigt, det er en uventet gevinst (jf. Barba, 2004), som efterfølgende bringes med ind i selve forestillingen.

I relation til serendipitet så er dette agentiale snit også et eksempel på den kollaborative proces og den type selvlæring, som er en del af arbejdet med forestillingen. Som indsat kan det være et øjeblik af mod og risiko, da kropslig berøring bag murene ofte er knyttet til udøvelse af vold eller magt over for hinanden. En del af at anvende serendipitet som kunstfagdidaktisk princip handler da om at skabe nogle rammer bag murene, som opleves som værende trygge at deltage i. Som publikum oplever jeg (Kristian), at det er et øjeblik af både noget intimt og intimiderende på samme tid. Spændingen mellem det intime og intimiderende kommer blandt andet til udtryk i det faktum, at jeg ved, at nogle af kroppene hører til indsatte og andre ikke. Denne uvidenhed sætter sit præg på måden, jeg selv som publikummer intra-agerer med hændelsen på. Det henleder min og muligvis også resten af publikums opmærksomhed på vores rolle som tilskuere i mødet med teaterhændelsens her og nu. Øjeblikket giver anledning til kritisk refleksion i forhold til eget syn på retssystemet i Norge specifikt og i verden generelt.

\footnotetext{
${ }^{3}$ Øvelsen er inspireret af Irwin Wurms "One minute sculptures”.
} 


\section{K. N. Knudsen $\mathcal{G}$ M. N. Knudsen}

\section{Innefra og Ut i en kunstfagdidaktisk kontekst}

I analysen har vi foretaget to agentiale snit i forskningsmaterialet, som glimtvis viser hvordan serendipitet som kunstfagdidaktisk princip kan bringes med ind i udviklingen af og mødet med en teaterforestilling. I analysen skabte vi fire performative agenter, henholdsvis kunstneriske benspend, materialiteten i fengslet, rummets materialitet og krop. Disse fire performative agenter er ikke de eneste, som indgår i de intra-aktioner, som fængslet som kunstinstitution indeholder, men de har haft størst betydning for vores møde med forestillingen. De agentiale snit, vi har gjort, og de performative agenter, som vi har skabt, er ikke de eneste som er i spil i de forskellige intra-aktioner, men vi har valgt disse, da de i vores kundskabsapparat, fremstår som de mest relevante i relation til vores fokus på serendipitet og hensigten med studien.

Barads begreber intra-aktion og agens, som er centrale begreber i agential realisme, indeholder også en etisk dimension, som bringes med ind i forskningsprocessen. I arbejdet med de indsatte bliver jeg (Marianne) som kunstner-forsker nødt til at forholde mig til institutionen jeg befinder mig i, og dens regler. Samtidig må jeg også overholde mine egne etiske regler for at arbejde med deltagerne. Eftersom deltagerne er kriminelle i et fængsel, så påvirkes jeg af dette i mødet med dem. Jeg har brugt lang tid på at kunne være i stand til at imødekomme den enkelte indsatte, som først og fremmest et menneske og ikke en kriminel. Ligeledes er jeg optaget af, at deltagerne ikke skal føle sig presset til at fremstille personligt materiale, uden at de forstår, hvad det eventuelt indebærer. Her opstår der også et etisk aspekt, da jeg i løbet af prøveperioden kan komme og gå, som jeg vil, men det kan de indsatte/deltagerne ikke. Deres personlige materiale bringes med tilbage til deres celler, det bliver siddende i væggene sammen med andre indsatte og ansatte, og de må forholde sig til dette, frem til de bliver løsladte. Arbejdet med forestillingen skal således ikke opleves som en dobbelt straf for den indsatte, ej heller for et eventuelt offer, som gennem mediernes dækning af arbejdet eller lignende genkender sin gerningsmand. Det er en til tider vanskelig balance at overholde og fordrer en særlig bevidsthed rettet mod det mangefold af etiske overvejelser, som følger i kølvandet af at arbejde med teater bag murene. Deltagerne, som er med i arbejdet, beskriver det som et brud i deres ellers rutineprægede hverdag, hvor de oplever at være et medmenneske fremfor at blive identificeret som en indsat. De oplever, at de tilhører et fællesskab, hvor også mødet med dem, som kommer udefra, er et møde med nye og andre impulser, både $i$ form af scenekunstnerne og publikum. Det handler altså ikke om at udstille eller udnytte de indsatte og deres erfaringer, men om at arbejde med at skabe fællesskab, hvor mødet mellem forskellige mennesker skaber en sammensat gruppe, som kan bygge bro mellem institutionen og samfundet uafhængigt af køn, etnicitet, handlinger eller fordomme.

De intra-aktive sammenfiltringer, som vi har skabt i mødet med Innefra og Ut, giver os selv som kunstner-forskere anledning til at stille spørgsmål ved, hvad der kan defineres som indefra og udefra og i stedet tale om forpligtende forbundethed 
og udleverethed (Juelskjær, 2019). Den etiske kompleksitet sætter sit præg på det kunstfagdidaktiske arbejde bag murene og fordrer en bevidsthed om egen sammenfiltring som kunstner-forsker. I forbindelse med udviklingen af Innefra og Ut bidrog jeg (Marianne), ligeledes selv med personligt materiale og som aktør på scenen. Det handler ikke om at udlevere sig selv og sine handlinger, men i stedet fokusere på, hvad vi har tilfælles; at være en far, en søn, en kæreste, en ven, en frivillig, en fagperson, en medborger og så videre. Derudover er jeg også bevidst om min (magt) position som ansvarlig for at overholde institutionens retningslinjer i forhold til sikkerhed og de magtsymboler, jeg bærer om min krop (nøgler og alarm). Dette forhold skaber, særligt i begyndelsen af projektet, forstyrrelser i relationen mellem deltagerne og undertegnede. De indsatte giver mig korte kommandoer, som for eksempel, at de skal på toilettet, at de vil ryge, eller at jeg skal hente kaffe til dem. Jeg sættes dermed i en "in-between" position i kraft af fængslets magtsymboler, samtidig med at jeg arbejder med et kunstnerisk projekt, som også indebærer at skabe et trygt, åbent og ligestillet fællesskab.

\section{Serendipitet som andethedserfaring}

Når vi læser forskningsmaterialet med teori fra agential realisme og serendipitetsbegrebet, så giver det os en mulighed for at fokusere på forskelle, som opstår i materieltdiskursive fænomener. Gennem de to agentiale snit har vi forsøgt at synliggøre, hvad det er, de performative agenter, vi har skabt/vi bliver opmærksomme på producerer. Disse brydninger og forbindelser som opstår gennem vores analyse, siger noget om måden, serendipitetsbegrebet kan adapteres til kunstfagdidaktisk arbejde med teater i fængsel på. Gennem fænomen-graferingen får kunstner-forskeren også mulighed for at bringe affektive impulser og stedets materialitet med ind i undersøgelsen af både den skabende proces og mødet med den kunstneriske hændelse.

Billede 2 viser konturerne af et kunstnerisk projekt, som har potentiale til at skabe øjeblikke af forandring for både publikum, deltagere og ansatte i og udenfor fængslet. Disse øjeblikke af forandring får os til at tænke på det, Nils Lehmann (2014) kalder andethedserfaringer. Lehmann beskriver andethedserfaringer som et forslag til at gentænke æstetik i en børne- og ungdomskulturel sammenhæng. Men andethedserfaringerne kan også bringes med ind i udviklingen og oplevelsen af Innefra og Ut. Ifølge Lehmann handler andethedserfaringer om at udvide børnenes erfaringer af de omgivelser, som de ganske vist kender ud og ind, men som de samtidig netop er holdt op med at åbne sig for, fordi de er blevet alt for velkendte (Lehmann, 2014, s. 79). I analysen af det første agentiale snit så beskriver jeg (Kristian), hvordan mødet med fængslet som kunstinstitution sætter sit præg på den erfaring, jeg får som publikummer. Jeg oplever at være blevet anderledes mig selv. Et andet eksempel er, når fængslets gymnastiksal transformeres til et gartneri med græsplæne, drivhus og planter. Her forsvinder det hverdagslige for en stund, hvilket medfører, at fængslets ansatte og indsatte erfarer de velkendte omgivelser på en anden måde. Eller, de får mulighed 


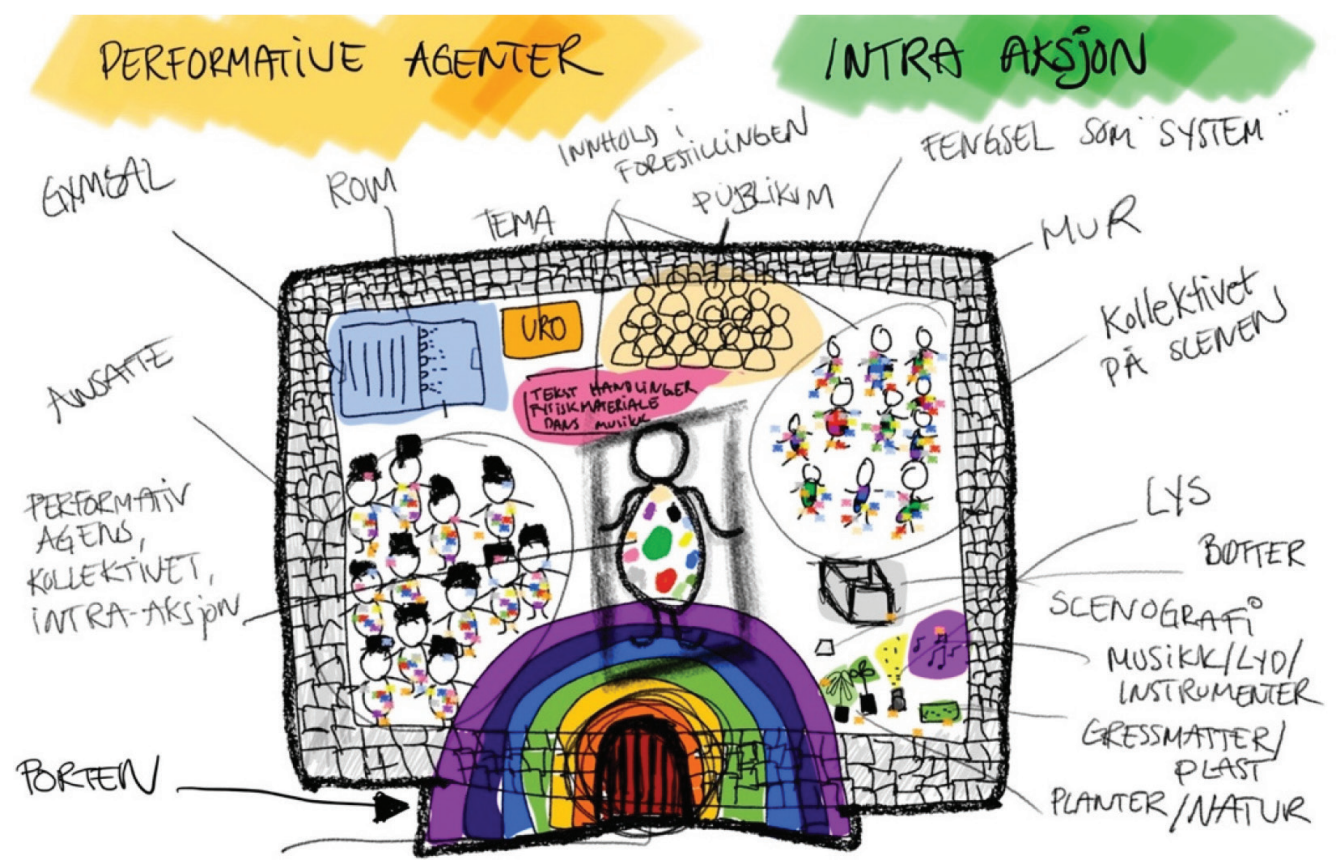

Billede 2. Med billedet tegner vi de intra-agerende performative agenter, som vi tillægger betydning, for at fængslet som kunstinstitution bliver til. (Design: Marianne Nødtvedt Knudsen)

for at se sig selv på ny. Disse øjeblikke af andetshedserfaring har også i sig kimen til at ryste på opfattelsen af fængslet som et lukket samfund og skabe dialog mellem verdenerne indenfor og udenfor murene.

\section{Serendipitet som kunstfagdidaktisk princip i teater bag murene}

I artiklens indledning skitserede vi tre indefra- og udefra-perspektiver, som har haft indflydelse på vores arbejde som kunstner-forskere $\mathrm{i}$ forbindelse med forestillingen Innefra og Ut. Det første perspektiv var tilknyttet Mariannes rolle som aktør og regi-ansvarlig i forbindelse med forestillingen. Det andet perspektiv relaterede sig til Kristians rolle som publikummer til forestillingen og det tredje og sidste perspektiv knyttede an til vores relation som samlevere. Med inkluderingen af Barads intraaktion og agens tilføres et fjerde perspektiv, som betoner forbundethed frem for inderog ydersider. Denne form for forbundethed har også sat sit præg på vores udforskning af serendipitetsbegrebet som kunstfagdidaktisk princip. Når kunstner-forskeren bringer serendipitet med ind i en kunstfagdidaktisk forskningskontekst, så fordrer det en opmærksom, åben og sensorisk årvågenhed ift. fysiske og sociale omgivelser (jf. Chemi \& Christoffersen, 2018). Men i mødet med agential realisme udvides betydningen af de fysiske og sociale omgivelser til også at inkludere ikke-menneskelig agens, materialitet, diskurser som studeres som sammenfiltrede fænomener, ikke som afgrænsede ting. Disse flettes sammen og bliver til i forskellige kunstneriske udtryk og handlinger. En 
del af dette arbejde medfører også, at kunstner-forskeren bringer affektive stemninger med ind $\mathrm{i}$ undersøgelsen og giver sig hen til sårbare og risikable øjeblikke. Denne form for årvågenhed over for det, som sker her-og-nu, og evnen til at synke ned i den skabende proces har også en kunstfagdidaktisk relevans. I analysen peger vi blandt andet på etik, risiko, delekultur, affekt, improvisation og en eksplorerende tilgang til processen som værende vigtige principper, som bringes med ind i det kunstfagdidaktiske arbejde i fængslet.

I fænomen-graferingen af de to hændelser fra forestillingen, identificerer vi fire performative agenter, som alle indvirker på undersøgelsen af serendipitet som kunstfagdidaktisk princip. I studien har vi beskrevet, hvordan materialiteter, diskurser og fænomener, som omgiver aktørerne/deltagerne, publikum og fængslet som institution, ko-konstitueres i den kunstneriske praksis bag murene. Disse hændelser indeholder en mulighed for at stille spørgsmål ved fængslet som kunstinstitution og ved tematikker knyttet til straf, rehabilitering, etik og humanitet. Derigennem åbnes der også op for en anden måde at forske på eller med teater i fængsel, som i denne studie har handlet om, at vi hverken har været fokuseret på deltagernes rehabiliteringsprocesser eller på det kunstneriske potentiale, som iscenesættelse af dramatik i et fængsel kan indeholde. I analysen har vi vendt fokus mod de forskelle og forbundetheder, som opstår i udviklingen og mødet med Innefra og Ut. Det er vanskeligt at sige noget om, hvorvidt arbejdet med forestillingen vil forandre fængslet som system eller samfundets syn på straf. Det vi kan sige noget om, er, at de andethedserfaringer, som vi har peget på flere steder i analysen, også indeholder et onto-epistemologisk aspekt. Den form for væren i verden som de erfaringer, de involverede i Innefra og Ut har været en del af (og her mener vi involverede $\mathrm{i}$ et udvidet perspektiv, såsom fængslet som institution, publikum, aktørerne/deltagerne) kan ikke adskilles fra, hvordan de samme mennesker har produceret kundskab om verden. Det samme gør sig gældende for os som forskere, da vi gennem vores møde med Innefra og Ut også kan siges at være blevet anderledes os selv.

\section{Forfatteromtale}

Kristian Nødtvedt Knudsen, PhD, arbejder som førsteammanuensis i teater ved institutt for visuelle og sceniske fag ved Universitetet i Agder. Kristian er en af hovedredaktørerne i JASEd og styremedlem i ASSITEJ Norge (http://assitej.no).

Marianne Nødtvedt Knudsen, Ma i anvendt drama og teater, arbejder som førsteamanuensis teater ved institutt for visuelle og sceniske fag ved Universitetet $\mathrm{i}$ Agder. Marianne er også scenekunstner og leder av Teater Bak Murene (NO).

\section{Referencer}

Balfour, M. (2000). Drama, masculinity and violence. Research in drama education. The fournal of Applied Theater and Performance, 5(1), 9-21. https://doi.org/10.1080/135697800114168

Barad, K. (2003). Posthuman performativity: Towards an understanding of how matter comes to matter. Signs, 28(3), 801-831. https://doi.org/10.1086/345321 


\section{K. N. Knudsen $\mathcal{G}$ M. N. Knudsen}

Barad, K. (2007). Meeting the Universe Halfway. Quantum Physics and the Entanglement of Matter and Meaning. Duke University Press.

Barad, K. (2014). Diffracting Diffraction: Cutting Together-Apart. Parallax, 20(3), 168-187. https://doi.org/ $10.1080 / 13534645.2014 .927623$

Barba, E. (2004). Stillhedens sønner. Overvejelser omkring Odin teaterets fyrre år. Til det skjulte folk - Odin Teaterets venner. Programmet til Andersens Drøm. Odin teateret.

Braidotti, R. (2013). The Posthuman. Polity.

Bottoms, S. (2010). Silent partners: Actor and audience in Geese Theatre's Journey Woman. Research in Drama Education: The fournal of Applied Theater and Performance 15(4), 477-496. https://doi.org/10.1080/135697 83.2010 .512183

Chemi, T., \& Christoffersen, E. E. (2018). Serendipitetens rum. Odin teaterets laboratorium. Klim forlag.

Dolphijn, R., \& van der Tuin, I. (2012). New materialism: Interviews \& cartographies. Open Humanities Press. http://dx.doi.org/10.3998/ohp.11515701.0001.001

Faulkner, S. L. (2018). Poetic Inquiry: Poetry as/in/for Social Research. I P. Leavy (Red.), Handbook of Arts-Based Research (s. 208-230). Guilford Press.

Gergen, K. J., \& Gergen, M. M. (2018). The performative movement in Social Science. I P. Leavy (Red.), Handbook of Arts-Based Research (s. 54-67). Guilford Press.

Goddard, L. (2013). From mainstream theaters to Synergy theater project: Black men's participation in "urban" plays in prison. Research in Drama Education: The fournal of Applied Theater and Performance, 18(4), 332-345. https://doi.org/10.1080/13569783.2013.836917

Haseman, B. (2006). A manifesto for performative research. Media International Australia incorporating Culture and Policy, 118(1), 98-106. https://doi.org/10.1177\%2F1329878X0611800113

Haagensen, C. (2014). Lived experience and Devised Theatre Practice: A Study of Australian and Norwegian Theatre Students'Devised Theatrical Practice [Doktorgradsafhandling]. NTNU Norges teknisk-naturvitenskapelige universitet.

Juelskjær, M. (2019). At tcenke med agential realisme. Nyt fra Samfundsvidenskaperne.

Keehan, B. (2015). Theater, prison \& rehabilitation: New narratives of purposes? Research in Drama Education:The Fournal of Applied Theater and Performance, 20(3), 391-394. https://doi.org/10.1080/13569783.2015.1060118

Knudsen, K. (2017). \#iLive-konturene af en performativ dramadidaktik i en digital samtid [Doktorgradsafhandling] . NTNU Norges teknisk-naturvitenskapelige universitet.

Kriminalomsorgen. (2019). Straff $i$ fengsel. 4.2.19 www.kriminalomsorgen.no/straff-i- fengsel.237611.no.html

Lehmann, N. (2014). En mangfoldighed af andethetserfaringer. I S. Graffer \& Å. Sekkelesten (Red.), Scenekunsten og de unge (s. 76-81). Norsk scenekunstbruk AS / Vidarforlaget AS.

Prendergast, M. (2013). Running around with inmates, maps and swords: A reflective poetic- narrative autoethnography of a prison theater production. Research in Drama Education:The journal of Applied Theater and Performance, 18(3), 331-323. https://doi.org/10.1080/13569783.2013.810927

Sutherland, A. (2013). Now we are real women: Playing with gender in a male prison theater programme in South Africa. Research in Drama Education: The fournal of Applied Theater and Performance, 18(2), $120-132$. https://doi.org/10.1080/13569783.2013.787262

Tett, L., Anderson, K., Mcneill, F., Overy, K., \& Sparks, R. (2012). Learning, rehabilitation and the arts in prisons: A Scottish case study. Studies in the Education og Adults, 44(2), 171-185. https://doi.org/10.1080/ 02660830.2012 .11661631

Thompson, J. (1998). Theatre and Offender Rehabilitation: Observations from the USA. Research in Drama Education: The Fournal of Applied Theater and Performance, 3(2), 197-210. https://doi.org/ 10.1080/1356978980030206

Woodland, S. (2016). The art of living in prison: A pragmatist aesthetic approach to participatory drama with women prisoners. Applied Theater Research, 4(3), 223-236. https://doi.org/10.1386/atr.4.3.223_1

Østern, A. L., \& Knudsen, K. N. (2019). Performative Approaches In Arts Education. Artful Teaching, Learning and Research. Routledge.

Østern, T. P., \& Letnes, M. (2017). Et temanummer som undersøker hva det innebærer å forske med kunsten. Fournal for Research in Arts and Sports Education. 1(5), 1-6. http://dx.doi.org/10.23865/jased.v1.1082 